\title{
Stress Management Through Yoga
}

\author{
Amaranath B* \\ S-VYASA Yoga University, India \\ Submission: January 27, 2017; Published: March 21, 2017 \\ *Corresponding author: Amaranath B, Director, S-VYASA Yoga University, India, Email: b_amaranath@yahoo.co.in
}

\section{Conceptual}

Stress is a very common with people of all ages across the globe and this has no boundaries and as to age, sex, religion. This factor needs to be addressed immediately, failing which there is going to be catastrophe for the very existence of human beings on this planet, just for the reason that, stress is found to be the root cause of social unrest.

With the advent of civilization, man has progressed in all spheres of life and his demands started creeping up. Though the progress in science and technology has made the human life more comfortable, his needs has increased and humans are becoming more and more machine dependent and humane values are gradually reduced and thus resulted in losing social values and bondages. The reason for all this is the rat race to excel over others and to acquire the modern gadgets. This has resulted in increased physical and mental stress, which has lead to various health hazards, and posing challenges in the society to address this issue on war footing to prevent disaster across the globe.

The modern medical system has evolved various techniques to measure the stress factor, and treat the same with various medicines. But this is found to be only temporary solution. The Ancient traditional holistic system of medicine such as Ayurveda, Yoga, Unanni, Sidda, Homeopathy (AYUSH) has come handy to resolve and mange stress apart from preventing and managing non communicable diseases like Diabetes, Hypertension, Cardiovascular, Cancer, Mental Health etc.

Yoga in particular is found to be very handy in enhancing physical and mental health and as a result, Yoga which was confined to Indian sub-continent, has spread across the world and intensive research activity is carried out across the globe to scientifically validate the effects of Yoga on mind and body. Vivekananda Yoga Anusandhana Samsthana (VYASA), Bengaluru, is carrying out extensive research in this direction under the guidance of its founder Dr HR Nagendra.

VYASA has developed new technique "Self Management of Excessive Tension-SMET which includes Deep Relaxation Technique (DRT), Quick Relaxation Technique (QRT) and Instant Relation Technique for 1 minute (IRT) to overcome stress and to attain higher energy levels, for enhanced efficiency of mind and body thus enabling to attend the required target. Most of the National and International institutes/organizations are making use of this technique for enhanced performance and to sustain in the current day competitive world.

Apart from the above VYASA has also evolved a Holistic Management System (HOLSYM) for effective management of day to day activities which adds dimensions of health, personality growth and contributions to the society to TQM.

Management techniques are being evolved regularly for effective Managing of Assets, Growth, achieving the projected targets/mile stone etc, Simillarly in order to meet the order of the hour, it essential that all those involved in setting new management trends/tools will also try to resolve the issue of increase in stress levels by making use of Holistic Health System for welfare of the mankind and peaceful existence on this universe. 
This work is licensed under Creative Commons Attribution 4.0 Licens

DOI: 10.19080/JCMAH.2016.01.555570
Your next submission with Juniper Publishers will reach you the below assets

- Quality Editorial service

- Swift Peer Review

- Reprints availability

- E-prints Service

- Manuscript Podcast for convenient understanding

- Global attainment for your research

- Manuscript accessibility in different formats

( Pdf, E-pub, Full Text, Audio)

- Unceasing customer service

Track the below URL for one-step submission https://juniperpublishers.com/online-submission.php 